\title{
O Cuidado Obstétrico na Percepção de Mulheres que Vivenciaram a Morbidade Materna Grave (Near Miss)
}

\author{
Aguiar, Cláudia de Azevedo; Tanaka, Ana Cristina D Andretta \\ Faculdade de Saúde Pública USP — claudia.azevedo@usp.br
}

INTRODUÇÃO a morbidade materna grave(near miss) é um evento evitável. Estudá-la e buscar a compreensão das necessidades de saúde das mulheres que têm esta experiência são importantes recursos na identificação das intervenções passíveis de prevenção e na transformação de práticas em saúde. OBJETIVO Compreender os significados do cuidado obstétrico recebido, por mulheres que vivenciaram o near miss materno. MÉTODOS Estudo qualitativo, que contou com o relato de 7 mulheres que vivenciaram o near miss, segundo critérios da OMS. As entrevistas ocorreram em dez/2013, após seleção feita pela Internet. RESULTADOS PARCIAIS Os resultados têm apontado o reconhecimento de fragilidades no cuidado recebido: "O anestesista chegou e disse: 'eu não quero ninguém mais aqui', tirou meu marido[...] e falou que ia me preparar para a anestesia[...] Só que de repente ele aplicou a agulha, sem avisar, e eu pulei de susto, eu não tava preparada. e ele disse: 'Não faz isso, senão você não vai tomar a anestesia!', e aquilo pra mim.... [grande suspiro]. Depois eu perguntei: 'Cadê meu marido?' e ele[o anestesista] disse: 'Aqui quem manda é a equipe!." (Andréa, 38 anos, hemorragia- UTI por 5 dias, Laparotomia póscesárea e hemotransfusão). "[No trabalho de parto] minha pressão continuava alta, mas eu estava dilatando, estava tudo indo bem. com $10 \mathrm{~cm}$, eu comecei a fazer força, porque era involuntário; eu tava na partolândia, como se diz[...] e a obstetriz falou: 'não faz força,porque a médica ainda não chegou', e aí, putz, que droga [lágrimas]. Pra mim,isso mudou tudo[...] Acho que esse momento pode ter influenciado o que houve comigo depois." (Daniela, 32 anos, eclâmpsia - UTI por 24h). "Passei muito mal a gravidez toda e ele [0 médico] sempre dizendo que era normal[...] Foram sete infecções urinárias até a $31^{\text {a }}$ semana[...] Até que tive uma febre de $42^{\circ}[. .$.$] Era pielonefrite e uma infecção grave no meu$ sangue. Foi só aí que fizeram outros exames, o ultrassom, que mostrou um rim único, doente[...]Fiquei 18 dias internada, perdi peso e fiquei longe do meu outro filho [lágrimas]." (Nicole,26 anos) "Com 7cm de dilatação, a médica disse que ia me ajudar, dilatando o resto com a mão[...]Depois disso, eu comecei a sangrar muito[...]Sentia um rio de sangue saindo de dentro me mim. Enquanto me costuravam, me deram uma aula de placenta, dizendo que a minha estava inteira[...] no quarto, eu desmaiei e não voltei mais[...]Fui para a cirurgia[...]e UTI; fiquei longe da minha bebê. Soube depois que era resto de placenta[...] Contratei uma equipe toda e nenhum deles foi me ver no pós-parto." (Patrícia,31 anos) CONCLUSÕES: a compreensão das mulheres acerca da experiência de near miss ultrapassa a dimensão biológica (quando se busca razões técnicas para o ocorrido). o cuidado profissional (ou a ausência dele) tem grande relevância nos discursos, tornando-se relacional com o desfecho negativo vivenciado.

Aguiar, Cláudia de Azevedo; Tanaka, Ana Cristina D Andretta. O Cuidado Obstétrico na Percepção de Mulheres que Vivenciaram a Morbidade Materna Grave (Near Miss). In: Anais do Congresso Internacional de Humanidades \& Humanização em Saúde [= Blucher Medical Proceedings, num.2, vol.1]. São Paulo: Editora Blucher, 2014. ISSN 2357-7282

DOI 10.5151/medpro-cihhs-10257 